\title{
Investigation of the Relationship between Pre-service Teachers' Lateral Thinking Levels and Problem-Solving Skills
}

\section{Öğretmen Adaylarının Yanal Düşünme Düzeyleri ile Problem Çözme Becerileri Arasındaki İlişkinin İncelenmesi}

\begin{abstract}
Akan Deniz YAZGAN*
Received: 10 September 2020

Research Article

Accepted: 26 October 2020

ABSTRACT: The purpose of this study is to determine to what extent problem-solving skill contributes to the prediction of lateral thinking. The sample of the research consisted of 475 undergraduate students, more specifically 357 female (75.2\%) and 118 male (24.8\%) students, attending the Faculty of Education at Çanakkale Onsekiz Mart University in Çanakkale, Turkey. The Problem-Solving Inventory - developed by Heppner and Petersen (1982) - and the Lateral Thinking Scale - developed by Semerci (2016) - were employed in the study to collect data. The descriptive statistics (frequency, percentage, arithmetic mean, and standard deviation) and multiple regression analysis were used to analyze the obtained data. According to the findings of the study, the lateral thinking levels of the teacher candidates were high, and their problem-solving skills were at a positive medium level. The teacher candidates' confidence in problem-solving ability and approach-avoidance scores positively affected their lateral thinking levels, on which their personal control scores exerted negative effects. In addition, the participating preservice teachers' total scores of problem-solving skills significantly predicted their lateral thinking scores.
\end{abstract}

Keywords: Lateral thinking, problem-solving, teacher training, teacher candidates.

ÖZ: Bu araştırmanın amacı, yanal düşünmenin yordanmasında problem çözme becerisinin ne düzeyde katkıda bulunduğunu belirlemektir. Araştırmanın çalışma grubunu Çanakkale Onsekiz Mart Üniversitesi Eğitim Fakültesi'ne devam eden $357 \mathrm{kız}$ (\%75.2), 118 erkek (\%24.8) toplam 475 üniversite öğrencisi oluşturmuştur. Araştırmada veri toplamak amaciyla Heppner ve Petersen (1982) tarafindan geliştirilen Problem Çözme Envanterive Semerci (2016) tarafindan geliştirilen Yanal Düşünme Ölçeği kullanılmıştır. Araştırmada elde edilen verilerin analizinde betimsel istatistikler (frekans, yüzde, aritmetik ortalama ve standart sapma) ve çoklu regresyon analizi kullanılmıştır. Araştırmada ulaşılan bulgulara göre, öğretmen adaylarının yanal düşünme düzeyleri yüksek, problem çözme becerileri pozitif orta düzeydedir. Öğretmen adaylarının problem çözme yeteneğine güven ve yaklaşma-kaçınma puanları, yanal düşünme düzeyini olumlu yönde etkilerken, kişisel kontrol puanları olumsuz yönde etkilemektedir. Ayrıca öğretmen adaylarının problem çözme becerisi toplam puanları, yanal düşünme puanlarını anlamlı olarak yordamaktadır.

Anahtar kelimeler: Yanal düşünme, problem çözme, öğretmen yetiştirme, öğretmen adayları.

Corresponding Author: Asst. Prof. Dr., Çanakkale Onsekiz Mart University, Çanakkale, Turkey, akandeniz@ hotmail.com, https://orcid.org/0000-0002-4607-6700

\section{Citation Information}

Yazgan, A. D. (2021). Investigation of the relationship between pre-service teachers' lateral thinking levels and problem-solving skills. Kuramsal Eğitimbilim Dergisi [Journal of Theoretical Educational Science], 14(1), 20-37. 
Industry 4.0, which can be expressed as a production revolution, and the new technological transformation it represents today confront the world with great challenges. It can be said that this transformation will affect every aspect of everyday life - e.g., ranging from production to logistics and from education to entertainment although the reflections of this process have not been fully understood in Turkey yet. In Kagermann, Wahlster, and Helbig's (2013) words, jobs in the context of Industry 4.0 by nature will most likely hold high expectations about complexity management, abstraction, and problem-solving from all employees in a workplace. In this context, some new skills, referred to as $21^{\text {st }}$-century skills, are conspicuously prevalent in the literature. Eryılmaz and Uluyol (2015) state that the most important of these skills are creativity, critical thinking, collaboration, and problem-solving, and underline that these skills become functional in an integrated manner. Hecklau, Galaitzke, Flachs, and Kohl (2016) list the skills expected from individuals in Industry 4.0 in four dimensions as technical, methodological, social, and personal competencies and emphasize creativity and problem-solving, which are considered directly related to lateral thinking (Lawrence \& Xavier, 2013), under the title of methodical competencies.

From a broader perspective, the role of creative thinking and problem-solving skills in the emergence of hunter-gatherer, agriculture, industry, post-industrial, and the Industry 4.0 societies in humanity's historical development is clear. In the struggle for survival with nature, human beings made stone tools for the continuation and welfare of their generation, opened huge channels to manage water resources, and invented money to expand trade and economy. In addition to all these developments, the systematization of the mind activity, called philosophy, thanks to Thales, his prediction of the exact time of the solar eclipse, the effort to understand the knowledge of nature using mathematics, astronomy, and philosophy can be regarded as the first manifesto of the skills known as creative thinking and problem-solving in the history of science and humanity. Inventions and discoveries that drive the progress of societies emerge as products of creative thinking and problem-solving (Senemoğlu, 2020). As Guilford (1967) puts it, creativity is needed to keep pace and to overcome many problems encountered in everyday life because creativity is the solution to the most serious problems of human beings.

Creative thinking requires the application of different problem-solving approaches through the effective use of available resources. In our education system, although different structural practices have been recently adopted in education and training, it is difficult to say that course contents are produced from a perspective that supports students' creativity and problem-solving skills. Karakuş (2001) expresses that "this superficial approach ultimately prevents intellectual growth and development and causes education to be short-breathed and superficial since, in order to learn a subject, it is necessary to reveal the connections and relationships between the parts of that particular subject, that is, to employ reasoning and thinking". It can be propounded that creative thinking can be discovered and improved in suitable environmental conditions and educational settings. However, although frequent references to these skills are included in the literature, the same does not hold true for their place in educational practices because learning and teaching processes, teacher competencies, and learning environment should be redesigned according to post-Industry 4.0 society - the new social paradigm - to reveal and develop creativity in students. 
Although they are called the $21^{\text {st }}$-century skills, these skills [(For example: creative thinking, innovativeness, critical thinking, problem-solving, communication, cooperation, learning to learn, effective verbal and written communication, information literacy, media literacy, information and communication technology literacy, flexibility to access and analyze information, adaptability, entrepreneurship, social and cultural skills, productivity, responsibility, leadership, reasoning, decision making, discussion, cognitive flexibility, curiosity, and imagination (Ecevit \& Kaptan, 2019)], most of which a qualified education system is expected to help individuals acquire, are unavailable in the education system of a great many countries - including Turkey -. Even if they theoretically exist in their systems, they cannot be imparted to students. It is known that education is one of the most effective tools in the treatment of all kinds of social diseases, especially the cases of violence that is very common in Turkey as well. The problem-solving and lateral thinking skills selected for the purpose of this research study are listed in the related literature as the $21^{\text {st }}$-century skills, which are directly related to creativity.

In this context, whether pre-service teachers' problem-solving skills predict their lateral thinking levels or not signifies the main problem of the study. It can be asserted that the findings of the study will be useful for decision-makers who shape educational policies, scholars who wish to look into the subject from different angles and viewpoints of scientific disciplines, and teachers who aspire to perfect their teaching processes.

\section{Lateral Thinking}

There are two commonly agreed-upon forms of thought. The first, which until recently prevailed in schools, books, and cultural narratives, is vertical thinking - the ability to follow a line of thought from the beginning to the end, to think in a linear pattern, or to break an idea down into its components. Vertical thinking, particularly associated with the paradigm characterized by limited access to information and with societies suffering from this depravity, is now being challenged by another way of constructing knowledge - i.e., lateral thinking. Edward de Bono, the founder of the theory of lateral and vertical thinking, states that "vertical thinking is about processing: we have some starting concepts, which are usually taken for granted, which we build on. Lateral thinking, on the other hand, is more concerned with perception, with examining and if necessary, changing these starting concepts and principles" (Braunstein, 1999). "Vertical thinking is best exemplified by the straight-arrow logic of the syllogism: $a=b, b=c$, so $a=c$. Lateral thinking, on the other hand, revels in creative juxtapositions and free association: dog>dogma>religion>Buddha" (Braunstein, 1999).

De Bono (1993) likens this cognitive mechanism to rain's forming channels on the ground. As he depicts, "rain falling onto a landscape will eventually form streams, rivers, and valleys. Once these have formed, future rainfall is channeled along these rivers and valleys. So the rain interacting with the landscape forms channels. which then affect the way future rain is collected and organized". "The brain has a marvelous ability to think, relate, analyze, synthesize and conclude in a matter of seconds; this, in turn, makes it a tough mission to think innovatively, since we need to force our brains to operate against their natures" (Hamza \& Hassan, 2016).

According to De Bono (1971a); lateral thinking consists of four stages: 1. recognizing dominant ideas that polarize the perception of a problem, 2. searching for 
different ways of looking at things, 3. relaxation of the rigid control of [vertical] thinking. Logical thinking is the prevention and classification of the flow of the thought with the label "No!". Vertical thinking catches the problem from the start. However, lateral thinking can develop a reverse perspective and can move forward, backward, and sideways, 4. the use of chance to encourage other ideas: In this method, the traditional thinking pattern must be broken and knowledge must be reorganized in a new way. In doing so, several techniques can be adopted, such as shifting attention between different aspects of the problem, necessarily allocating a share to alternative solutions, changing a concept, and breaking up the parts of a concept into sections and subsections-or doing the opposite - rearranging sections between parts in a new way.

Lateral thinking is defined as "seeking to solve problems by unorthodox or apparently illogical methods". The term was introduced as a means of moving sideways when working on a problem to try different perceptions, ideas, and points of entry. Lateral thinking is concerned with the generation of new ideas. New ideas are the stuff of change and progress in every field from art to science and politics to personal happiness. It is a habit of thinking more than the application of some techniques of thinking. Its usefulness of an outside view of a problem is that it lends itself to the emergence of a new point of view; therefore, it refuses fruitless manners of thinking baffling individuals when they are very close to solving a problem. (Burgh, 2005; De Bono, 1971b; Lawrence \& Xavier, 2013; Rossdale, Martin, \& Jeffcott, 2003).

Lateral thinking is also thought as a crucial component of creative thinking (De Bono, 1999). As Lindell (2011) suggests, "creativity refers to an ability to generate original, novel, flexible, and useful ideas that are not constrained by established mental habits". "Creativity is the production of the new, original, unique, and divergent products and ideas mediated through lateral thinking" (Lamb, Annetta, \& Vallett, 2015). "There is considerable pressure to promote creativity and fluency as a means to develop the next generation of technological and scientific innovations within government agencies and companies. For example, the National Science Foundation, Intel, Microsoft, and Google all engage in competitive funding awards specifically identifying creativity as a goal. Other organizations also routinely offer contests promoting large awards for innovation and creative applications of science" (Lamb et al., 2015).

\section{Problem-Solving}

In the literature, problem as a term is defined in various ways. Some researchers define "problem" as a phenomenon that contains uncertainty and suspicion, while others as information that can be accessed through continuous research (Dostal, 2015; Ün, 2010). Problem-solving can be referred to as a mental and intellectual process of finding problems and solving on the basis of accurate data and information, so that appropriate and careful conclusions can be drawn (Winarti, Ichsan, Listyarini, \& Hijriyanti, 2019). Solving problems/conflicts involves forms of cognitive/behavioral efforts to regulate adverse situations and to overcome problems. In solving problems of the real world, students can obtain the knowledge and skills that they will need after they graduate (de Almeida \& Benevides, 2018; Docktor \& Mestre, 2014; Heppner \& Baker, 1997). Besides, an individual with problem-solving skills grows up as a self-confident individual who can think creatively and independently (Güneri Yöyen, Azaklı, Üney, \& Demirci, 2017). Today's learners need specific skills, such as problem-solving, 
scientific literacy, creativity and innovation, communication, collaboration, reasoning and critical thinking to prepare for an increasingly complex life (Alfin, Fuad, Nur, Yuanita, \& Prahani, 2019; Demirel \& Y1lmaz, 2019; Irwanto, Saputro, Rohaeti, \& Prodjosantoso, 2018). Moreover, schools must move beyond the typical focus on basic competency in core subjects to promoting understanding of the content at much higher levels by integrating the $21^{\text {st }}$-century skills into all subject areas (Husain, Kamal, Ibrahim, Huddin, \& Alim, 2017).

Generally, a problem-solving process includes information categorization from the problem statement to be visual symbolic information, as well as a piece of writing that applies an appropriate concept for problem-solving (Mulyastuti, Sutopo, \& Taufiq, 2018). D'Zurilla and Nezu (1990) note that the problem-solving process has five steps: 1. Problem definition, 2. Problem formulation, 3. Generation of alternative solutions, 4. Making decisions by evaluating the results of the options, 5. Implementing the decision and verification. Successful problem solvers often use analogical reasoning to solve a new problem by recognizing a corresponding schema in long-term memory that has the same structural characteristics, abstracting the solution method from the schema, and applying it to the target problem (Stahovich, Van Arsdale, \& Mayer, 2019).

According to Malik et al. (2019), problem-solving skill is a complex and very important skill as a part of the learning process in all disciplines and it can be acquired and improved by students through learning and laboratory activities. Some experts believe that problem-solving is a sub-category of critical thinking, while others argue that these two concepts overlap (Karantzas et al., 2013). It can be concluded from the literature review that the acquisition of critical thinking and problem-solving skills can be improved through the implementation of collaborative inquiry-based learning in which the learning process is focused on developing metacognitive skills, such as building a solution, testing the solution, and evaluating the results (Irwanto et al., 2018). Problem-based learning is another learning method to use real-life problems. This student-centered method begins by defining the real-world problem and then solves it (Parno \& Ni'mah, 2018).

Problem-solving is the basis of many academic learning processes and therefore considered as the main goal of education (OECD, 2013). Problem-solving cannot be abstracted from everyday life, and in order to define a person as a problem solver, it is necessary to be able to use the solutions or answers used in different problems, as well as in the more analytical problems they encounter. Since every activity in the future working life will include different and complex problems, it can be stated that every teacher candidate should have expert-level problem-solving competence (Şener, 2019; Widodo, Darhim, \& Ikhwanudin, 2018).

\section{Purpose}

In this study, it is aimed to examine whether the lateral thinking levels of prospective teachers are predicted by their problem-solving skills. For this purpose, answers to the following research questions are sought:

1. What are the lateral thinking levels of prospective teachers?

2. What are the levels of teacher candidates' problem-solving skill according to: a. Confidence in problem-solving 

b. Approach-avoidance
c. Personal control

3. Can prospective teachers' lateral thinking levels be predicted according to problem-solving skills sub-dimensions and total problem-solving scores?

\section{Method}

In order to put the problem and solution of the research into context, firstly the scientific literature on the subject was reviewed, during which previous studies similar to the research subject were examined. Based on these studies, the research problem was produced. In the next stage, the aims, methods, results, and sources of similar studies were examined, and the method and the needed sources were determined.

\section{Research Model}

The paper is a quantitative correlational research study. Quantitative research methods focus on objective measurements through statistical analyses or numerical data collection. Data is collected by a variety of tools, such as scales and questionnaires (Creswell, 2009). According to Gravetter and Forzano (2012), one of the important uses of relational research is its ability to establish a relationship between variables that can be used for predictive purposes. In a relational study, two variables studied are basically equivalent. However, relational studies generally define one variable as the predictive variable and the second as the criterion variable. In this study, firstly, the relationship between lateral thinking and problem-solving was examined and depending on the significance of the relationship, whether the level of problem-solving, which was determined as the predictor variable, had an effect on the lateral thinking level determined as the criterion variable was investigated.

\section{Sample}

The population of the research consists of the pre-service teachers studying in the undergraduate programs in the Faculty of Education at Çanakkale Onsekiz Mart University, adding up to 4500 teacher candidates. The sample consists of 475 participants. Stratified sampling, which is a type of sampling that aims to represent subgroups/strata in the universe in proportion to their weights in the universe Büyüköztürk, Kılıç-Çakmak, Akgün, Karadeniz, and Demirel (2012) was adopted to produce the sample. While creating layers, the features of homogeneous groups were taken into account. The study layers are Social Studies Teaching, Japanese Language Teaching, Science Teaching, English Language Teaching, Turkish Language Teaching, Art Teaching, Music Teaching, German Language Teaching, and Psychological Counseling and Guidance. In stratified sampling, different sampling techniques can be used for subsamples. Subsamples in each stratum are determined by cluster sampling. The clusters denote the $1^{\text {st }}-, 2^{\text {nd }}-, 3^{\text {rd }}-$, and $4^{\text {th }}$-year classes. The participants selected from the subsamples were included in the study with simple random sampling (Matthews \& Ross, 2010). 
Table 1

Descriptive Statistics Regarding Sampling

\begin{tabular}{|c|c|c|c|}
\hline & & $f$ & $\%$ \\
\hline \multirow[t]{2}{*}{ Gender } & Male & 118 & 24.8 \\
\hline & Female & 357 & 75.2 \\
\hline \multirow{4}{*}{ Class } & $1^{\text {st }}$-year students & 282 & 59.4 \\
\hline & $2^{\text {nd }}$-year students & 45 & 9.5 \\
\hline & $3^{\text {rd }}$-year students & 70 & 14.7 \\
\hline & $4^{\text {th }}$-year students & 78 & 16.4 \\
\hline \multirow{9}{*}{ Department } & Social Studies Teaching & 49 & 10.3 \\
\hline & Japanese Language Teaching & 24 & 5.1 \\
\hline & Science Teaching & 153 & 32.2 \\
\hline & English Language Teaching & 34 & 7.2 \\
\hline & Turkish Language Teaching & 75 & 15.8 \\
\hline & Art Teaching & 19 & 4.0 \\
\hline & Music Teaching & 32 & 6.7 \\
\hline & German Language Teaching & 11 & 2.3 \\
\hline & Psychological Counseling and Guidance & 78 & 16.4 \\
\hline
\end{tabular}

As clear from Table 1, a total of 475 teacher candidates participated in the study. of the $1^{\text {st }}, 2^{\text {nd }}, 3^{\text {rd }}$, and $4^{\text {th }}$-year students account for $59.4 \%$ (282 students), $9.5 \%$ (45 students), $14.7 \%$ (70 students), and $16.4 \%$ (78 students), respectively. The table also reveals that the pre-service teachers who were included in the participants studying in Science Teaching correspond to the highest (32.2\%) and in German Teaching to the lowest percentage $(2.3 \%)$. Of the teacher candidates participating in the study, $75.2 \%$ (357 students) are female and 24.8\% (118 students) are male.

\section{Ethical Considerations and Data Collection Tools}

At this stage of the study, the characteristics of the measurement tools used in the data collection process, how reliability was assessed, and the results of the assessment are presented. The Problem-Solving Inventory - developed by Heppner and Petersen (1982) - and the Lateral Thinking Disposition Scale, whose validity and reliability were studied by Semerci (2016), were used for data collection. Each measurement tool is explained separately in the following sections.

Ethical approval and written permission were obtained from the Scientific Research Ethics Committee of Çanakkale Onsekiz Mart University (dated 07.09.2020 and numbered 2020-25), respectively. Ethical rules were followed at all stages of research. The research participants participated in the research on a voluntary basis. In this context, the aim and the method of the study were introduced to the students, and their verbal permissions were also obtained. 
Problem Solving Inventory. The Problem-Solving Inventory was developed by Heppner and Petersen (1982). Heppner and Petersen (1982) proposed a five-step problem-solving model (general orientation, definition of the problem, alternative generation, decision making, and evaluation). However, the factor analysis results regarding the construct validity of the developed 35-item scale did not support the five stages determined. The analysis yielded a three-factor structure. These are (1) confidence in problem-solving, (2) approach-avoidance, and (3) personal control (Heppner, Witty, \& Dixon, 2004). Confidence in problem-solving ability refers to an individual's sense of confidence in problem-solving skills, approach-avoidance to his/her willingness to cope with difficult problems, and personal control to the feeling that the individual is in control of the situation (Heppner \& Petersen, 1982).

The inventory consists of 35 items that describe how people react to their personal and everyday life problems. It is a six-point Likert-type inventory. Of these, (1) indicates "strongly disagree", while (6) denotes "strongly agree". Scores ranging between " 1 " and " 6 " are assigned to each answer. At the time of scoring 9 "th, $22^{\text {nd }}$. and $29^{\text {th }}$ items are excluded from scoring. Items 1,2 , 3, 4, 11, 13, 14, 15, 17, 21, 25, 26, 30, and 34 are scored reversely. The inventory consists of three sub-domains: "confidence in problem-solving ability", "approach-avoidance", and "personal control". Trust in problem-solving ability is represented by 11 items (items 5, 10, 11, 12, 19, 23, 24, 27, 33, 34, and 35), approach-avoidance by 16 items (items 1, 2, 4, 6, 7, 8, 13, 15, 16, 17, $18,20,21,28,30$, and 31), and personal control by five items (items 3, 14, 25, 26, and $32)$.

It was concluded after consulting the subject matter experts before the application that there was no problem regarding the content validity. In the evaluation of the scores harvested with the scale, it was resolved to take into account the average score instead of the total score range of 32-192 in order to include the sub-dimensions in the analysis. Hence the average scores between 1 and 6 points were included in the evaluation. The points and their respective descriptions are as follows:

1.00-1.49: Very low; 1.50-2.49: Low; 2.50-3.49: Negative intermediate; 3.504.49: Positive intermediate; 4.50-5.49: High; 5.50-6.00: Very high.

The internal consistency coefficient was calculated to assess the reliability of the Problem-Solving Inventory. The Cronbach's Alpha value was calculated as .834 for the sub-domain of 'confidence in problem-solving ability', .794 for 'approach-avoidance', .682 for 'personal control', and .848 for the total inventory. It was understood that the measuring tool was reliable.

Lateral Thinking Disposition Scale. Lateral Thinking Disposition Scale was developed by Semerci (2016). The scale is a 5-point Likert scale, the levels of which range from "totally disagree" to "totally agree". It consists of nine items and one domain. In line with the data obtained in the study, it was concluded that the factor loads in the scale occurred between .41 and .70 and the item total correlation values of the items between .47 and .67 , and the reliability coefficient was calculated to be .754 . According to the results obtained, the scale was valid and reliable. Consulting with the experts of the subject before the application warranted that there was no problem regarding the content validity. For the reliability analysis of the Lateral Thinking 
Disposition Scale, the internal consistency coefficient was calculated to be.786. The points and their descriptions are as follows:

1.00-1.49: Very low; 1.50-2.49: Low; 2.50-3.49: Intermediate; 3.50-4.49: High; 4.50-5.00: Very high.

\section{Data Analysis}

In the interpretation of quantitative data, a significance level of $p=.05$ was adopted to judge upon the statistical significance of the differences. Descriptive statistical techniques were used to analyze the data concerning the first and second research questions. In this context, frequency, percentage, arithmetic mean, and standard deviation values were calculated. Multiple regression analysis was performed to assess the third research question. SPSS 23.0, a statistical software program, was used to analyze the quantitative data.

\section{Results}

In this part of the study, the quantitative findings obtained in the research are presented in tables, and the comments on the findings are included.

\section{Lateral Thinking Levels of Teacher Candidates}

The lateral thinking levels of the teacher candidates are tabulated below.

Table 2

Lateral Thinking Levels of Participants

\begin{tabular}{cccccccc}
\hline & Very low & Low & Intermediate & High & Very high & $\bar{X}$ & ss \\
\hline$f$ & 0 & 11 & 81 & 341 & 42 & 3.9 & .5 \\
$\%$ & .0 & 2.3 & 17.1 & 71.8 & 8.8 & & \\
\hline
\end{tabular}

As clear from Table 2, the lateral thinking levels of the teacher candidates range from 'low' to 'very high'. The levels of $2.3 \%$ (11) of the teacher candidates are low, $17.1 \%(81)$ are medium, $71.8 \%$ (341) are high, and 8.8\% (42) are very high. It can be said that the average scores of the teacher candidates $(\bar{X}=3.9)$ are at a high level.

\section{Problem-Solving Skill Levels of Teacher Candidates}

The problem-solving skill levels of the teacher candidates are presented below.

Table 3

Problem-Solving Skill Levels of Participants

\begin{tabular}{|c|c|c|c|c|c|c|c|c|c|}
\hline Domain & & $\begin{array}{l}\text { Very } \\
\text { low }\end{array}$ & Low & $\begin{array}{c}\text { Negative } \\
\text { intermediate }\end{array}$ & $\begin{array}{c}\text { Positive } \\
\text { intermediate }\end{array}$ & High & $\begin{array}{l}\text { Very } \\
\text { high }\end{array}$ & $\bar{X}$ & ss \\
\hline \multirow{2}{*}{$\begin{array}{l}\text { Confidence in } \\
\text { problem-solving }\end{array}$} & $f$ & 0 & 2 & 48 & 193 & 209 & 23 & \multirow{2}{*}{4.5} & \multirow{2}{*}{.7} \\
\hline & $\%$ & .0 & .4 & 10.1 & 40.6 & 44.0 & 4.8 & & \\
\hline \multirow[t]{2}{*}{ Approach-Avoidance } & $f$ & 0 & 2 & 37 & 233 & 193 & 10 & \multirow{2}{*}{4.3} & \multirow{2}{*}{.6} \\
\hline & $\%$ & .0 & .4 & 7.8 & 49.1 & 40.6 & 2.1 & & \\
\hline
\end{tabular}




\begin{tabular}{lccccccccc}
\hline Personal Control & $f$ & 0 & 13 & 128 & 277 & 57 & 0 & 3.8 & .6 \\
\cline { 2 - 8 } & $\%$ & .0 & 2.7 & 26.9 & 58.3 & 12.0 & .0 & \\
\hline $\begin{array}{l}\text { Problem-Solving } \\
\text { (Total Score) }\end{array}$ & $f$ & 0 & 1 & 27 & 271 & 175 & 1 & 4.3 & .5 \\
\cline { 2 - 8 } & $\%$ & .0 & .2 & 5.7 & 57.1 & 36.8 & .2 & & \\
\hline
\end{tabular}

Table 3 exhibits that the problem-solving skill levels of teacher candidates range between 'low' and 'very high'. The levels of problem-solving skills of the participants were examined in consideration of the sub-dimensions and the total scale scores.

The analysis of the subscale of 'confidence in problem-solving ability' revealed that the average scores of the participants $(\bar{X}=4.5)$ were high. The confidence levels of $40.6 \%$ (193) of the participants are positive medium, of 44.0\% (209 participants) are high, and of $4.8 \%$ (23 participants) are very high. Only $10.1 \%$ (48 respondents) are moderate negative and are reluctant to place trust in their problem-solving ability. It was concluded from these findings that teacher candidates generally have confidence in their problem-solving skills.

The examination of the approach-avoidance sub-domain showed that the levels of the average scores of the participants $(\bar{X}=4.3)$ are positive intermediate. The levels of $49.1 \%$ (233) of the participants are positive intermediate, of 40.6\% (193) are high, and of $2.1 \%$ (23) are very high. $7.8 \%$ (37) of the participants are at a negative intermediate level and it can be realized that they are hesitant in the approach-avoidance domain. Based on these findings, it can be said that teacher candidates are generally at a positive intermediate level in the approach-avoidance subscale, which can also be expressed as the interventional-practical dimension of problem-solving.

It was understood in regards to the domain of personal control that the mean scores of the participants $(\bar{X}=3.8)$ were negative intermediate. The levels of $58.3 \%$ (277) of the participants are positive intermediate, of 26.9\% (128 participants) are negative intermediate, and of $12 \%$ (57 participants) are high. Based on these findings, it was understood that the teacher candidates were at a medium level in the personal control subdomain, which can be regarded as the decision-making-implementation dimension of problem-solving.

The analysis of the Problem-Solving Inventory on the basis of total scores indicated that the average scores of the participants $(\bar{X}=4.3)$ were positive intermediate. The level of $57.1 \%$ (271) of the participants are positive intermediate, of $36.8 \%$ (175) are high, and of $5.7 \%$ (27) are negative intermediate. Based on this finding, it can be stated that the levels of the pre-service teachers' problem-solving skills are positive and intermediate.

\section{Relationship between Teacher Candidates' Lateral Thinking Levels and Problem-Solving Skill Levels}

In this part, firstly the teacher candidate's problem-solving skill levels were separately determined in view of 'confidence in problem-solving', 'approachavoidance', and "personal control". Then, they were collectively presented as the total score and whether there was a relationship between lateral thinking levels was questioned. The predictive analysis was conducted under two models for each examination. 
Table 4

Analysis Results Related to Problem-Solving Skill Level Predicting Lateral Thinking Level

\begin{tabular}{|c|c|c|c|c|c|c|c|c|c|}
\hline & $\begin{array}{l}\text { Predictive } \\
\text { Variable }\end{array}$ & $B$ & $\begin{array}{c}\text { Standard } \\
\text { Error } B\end{array}$ & $\beta$ & $t$ & $p^{*}$ & $\begin{array}{l}\text { Partial } \\
r\end{array}$ & $\begin{array}{c}\text { Part } \\
r\end{array}$ & \\
\hline \multirow{4}{*}{ Model 1} & Constant & 2.621 & .194 & & 13.509 & .000 & & & \multirow{2}{*}{$\begin{array}{l}\text { Multiple } \\
R=.36 \\
R^{2}=.13 \\
\text { Adjusted } \\
R^{2}=.13\end{array}$} \\
\hline & $\begin{array}{l}\text { Confidence } \\
\text { in } \\
\text { Problem- } \\
\text { Solving }\end{array}$ & .172 & .038 & .230 & 4.573 & .000 & .206 & .196 & \\
\hline & $\begin{array}{l}\text { Approach- } \\
\text { Avoidance }\end{array}$ & .187 & .044 & .218 & 4.294 & .000 & . 194 & .184 & $\begin{array}{l}R^{2}=.13 \\
F=23.909\end{array}$ \\
\hline & $\begin{array}{l}\text { Personal } \\
\text { Control }\end{array}$ & -.088 & .039 & -.105 & -2.276 & .023 & -.104 & -.098 & $\begin{array}{l}F=23.909 \\
p<.05\end{array}$ \\
\hline \multirow{4}{*}{ Model 2} & Constant & 2.445 & .191 & & 12.835 & .000 & & & \multirow{2}{*}{$\begin{array}{l}\text { Multiple } \\
R=.33 \\
R^{2}=.11\end{array}$} \\
\hline & \multirow{3}{*}{$\begin{array}{l}\text { Problem- } \\
\text { Solving }\end{array}$} & .331 & . 044 & .326 & 7.500 & .000 & .326 & .326 & \\
\hline & & & & & & & & & $\begin{array}{l}\text { Adjusted } \\
R^{2}=.10\end{array}$ \\
\hline & & & & & & & & & $\begin{array}{l}F=56.249 \\
p<.05\end{array}$ \\
\hline
\end{tabular}

$* p<.05$

The first model was found to be statistically significant in predicting the lateral thinking levels of the prospective teachers $\left[R^{2}=.13\right.$, Adjusted $\left.R^{2}=.13, F=23.909, p<.05\right]$. Confidence for problem-solving ability scores of the teacher candidates significantly predicted lateral thinking scores $(\beta=.230, p<.05)$. Approach-avoidance scores significantly predicted lateral thinking scores $(\beta=.218, p<.05)$. Personal control scores too significantly predicted lateral thinking scores $(\beta=-.105, p<.05)$. According to these results, while teacher candidates' confidence in problem-solving ability and approachavoidance scores positively affected lateral thinking level, it was negatively affected by personal control scores. The regression model equation is as follows:

Lateral Thinking $=2.621+(.172 *$ Confidence in Problem-Solving $)+$ $(.187 *$ Approach-Avoidance $)+(-.088 *$ Personal control $)$

The second model was statistically significant in predicting the lateral thinking levels of the pre-service teachers $\left[R^{2}=.11\right.$, Adjusted $\left.R^{2}=.10, F=56.249, p<.05\right]$. The teacher candidates' total scores of problem-solving skills significantly predicted lateral thinking scores $(\beta=.326, p<.05)$. According to this result, the teacher candidates' total problem-solving scores positively affected lateral thinking level. The regression model equation is as follows:

Lateral Thinking $=2.445+(.331 *$ Problem-Solving $)$ 


\section{Discussion and Conclusion}

According to the initial finding of the study, the lateral thinking levels of the teacher candidates were high. This finding supports the findings of similar studies conducted on primary school teacher candidates (Y1ld1z \& Y1lmaz, 2020) and students of teacher training (for non-educational departments) (Semerci, 2017). These researchers have found that the lateral thinking tendencies of prospective teachers are high and at expected levels. On the other hand, Evin Gencel (2018), who conducted her study on primary school teacher candidates attending three state universities in the Marmara Region, has found that lateral thinking tendencies are at a moderate level. In the same study, it is reported that those who have reading habits and frequently use social media have higher levels of lateral thinking disposition. Karagöz (2019), who has investigated the lateral thinking tendencies of 197 pre-service teachers in terms of gender, grade, school type, reading habits, and internet use, and has concluded that there was no significant difference between the lateral thinking tendencies of pre-service teachers in consideration of all the variables.

According to Lawrence and Xavier (2013), lateral thinking is a way of thinking that seeks solutions to difficult problems with elements that can normally be ignored with unconventional methods or logical thinking. In other words, lateral thinking focuses on seeing the "big picture" from different angles. Therefore, the products of thought emerging in such a process are also of higher value than those realized solely based on traditional or logical thinking because lateral thinking is both the initiator and the most indispensable component of creative thinking. In terms of the efficiency of the educational process, it is important that teacher candidates have high lateral thinking skills as they will become effective actors in gaining lateral thinking skills in their future careers. In this context, instead of activities and tasks where teacher candidates can access information from a single source during their pre-service training, it would be beneficial to offer them activities that will support their different perspectives on the world and on their personal and social domains and boost their intellectual and social development.

According to the second finding obtained in the study, the problem-solving skills of the teacher candidates are at a positive intermediate level. However, it was understood pertaining to the subscales that the level of the personal control subdimension of problem-solving was lower in terms of the mean score than that of the subdomains confidence in problem-solving and approach-avoidance. In the study conducted on 406 pre-service teachers by Kolayiş and Turan (2018), the subdomains are not taken into consideration and it has been found that the perceived problem-solving skill scores of teacher candidates are below the intermediate level. Eyvaz (2017) has found that pre-school teacher candidates' problem-solving skills were low. Üstündağ and Beşoluk (2012) have concluded that although there is a significant difference in problem-solving skills in terms of gender, school, and education type, there is no statistically significant difference according to the results of the Problem-Solving Inventory, which has been filled out by pre-service science teachers; besides, they have found that problem-solving skills differ according to class standing. Şahin, İbili, and Uluyol (2017) have concluded that pre-service teachers have moderate and high levels of self-perceptions in terms of problem-solving tendencies, and they consider themselves more planned and self-confident than emotional, intuitive, and avoidant. 
Problem-solving skill is among the social and emotional competencies and one of the high-level thinking skills that all individuals have at various levels (Frey, Hirschstein, \& Guzzo, 2000). From a philosophical perspective, it can be stated that human life is a long problem-solving process. In the education of their student, teacher candidates who will have a critical role in their personal, social and cognitive development can be said to be in need of practice-oriented courses or activities to be implemented in different courses, enriched with different contents that will support the development of - problem-solving skills during their pre-service training. In addition, it was understood that the scores of the personal control subdomain were lower than those of the others. The personal control domain emphasizes decision making and implementation. Altun (2003) underlines that people who see themselves as systematic and determined individuals also see themselves as having correct problem-solving skills. Duman, Yakar, Türkoğlu, and Yakar (2013) have found that pre-service teachers who think that they do not have emotional fluctuations and who think they are not extroverted, open to experience, and responsible have higher levels of problem-solving skills. In this context, it can be said that confronting prospective teachers with different types of problems, supporting them to make sound and consistent decisions in the problem-solving process, and encouraging them in lessons can have positive effects.

According to the last finding, while the confidence of the teacher candidates in problem-solving ability and approach-avoidance scores positively affected lateral thinking level, personal control scores negatively affected them. In addition, pre-service teachers' total scores of problem-solving skills significantly predicted their lateral thinking scores $(\beta=.326, p<.05)$. As clear from these results, the pre-service teachers' total problem-solving scores positively affected their lateral thinking level. It is remarkable that the self-control variable has a negative effect on problem-solving. In other words, teacher candidates experience some limitations in managing the problemsolving process. It can be claimed that there is a need for new research to be conducted in different stages, fields, and disciplines to substantiate this finding.

Lateral thinking and problem-solving skills handled in the present study are referred to as high-order thinking skills in PISA, conducted triennially by the Organization for Economic Co-operation and Development (OECD) and prominent as an international educational indicator. This is because lateral thinking incorporates different perspectives on phenomena, whereas problem-solving embodies the efforts favoring technical and scientific methods intended for the analysis and solution of these phenomena. Level 5 and 6 in PISA 2018 refer to significant cognitive skills different from the other levels in terms of both lateral thinking and problem-solving skills (For example, Level 5 students can use abstract scientific ideas or concepts to explain unfamiliar and more complex phenomena, events and processes; apply more sophisticated epistemic knowledge to evaluate alternative experimental designs and justify their choices and use theoretical knowledge to interpret information or make predictions. Level 6 students can draw on a range of inter-related scientific ideas and concepts from the physical, life and earth and space sciences and use content, procedural and epistemic knowledge in order to offer explanatory hypotheses of novel scientific phenomena, events and processes or to make predictions; distinguish between arguments that are based on scientific evidence and theory and those based on other considerations. Besides, according to PISA 2018, students in Turkey are incompetent in 
Level 5 and 6 in terms of science literacy and these students account for 85.3\% (Aydin Ceran, 2019).

Traditional approaches to teacher training fall short of satisfying professional demands (UNESCO, 2002). Among the most important duties of a teacher in the learning-teaching processes is to contribute to the development of their students' thinking skills. One of the most effective ways to achieve this is to design the course contents, learning environment, and teaching methods and techniques needed by the teacher in a way to help them acquire these skills. In the post-Industry 4.0 society, robot teachers now enter classrooms, programs based on artificial intelligence dominate students, teachers, and learning environments, and high-tech-based efforts challenge education systems all around the globe. In such a process, pre-service training of prospective teachers should focus on how to equip students with what is called $21^{\text {st }}$ century skills. Furthermore, it can be said that there is a need for research on these skills, especially lateral thinking and problem-solving skills of students at different levels. It can be suggested that different data collection techniques and different theoretical variables should be used in future studies on the subject. 


\section{References}

Alfin, J., Fuad, A. Z., Nur, M., Yuanita, L., \& Prahani, B. K. (2019). Development of group science learning (GSL) model to improve the skills of collaborative problem solving, science process, and self-confidence of primary schools teacher candidates. International Journal of Instruction, 12(1), 147-164.

Altun, İ. (2003). The perceived problem solving ability and values of student nurses and midwives". Nurse Education Today, 23, 575-584.

Aydın Ceran, S. (2019). PISA 2018 perspektifinde fen bulgularına Türkiye özelinde genel bakış. Retrieved from http://arastiranokul.org/wpcontent/uploads/2019/12/PISA-2018-FEN-OKUR-YAZARLI\%C4\%9EI.pdf on October 2, 2020.

Braunstein, P. (1999). The case for lateral thinking: Discerning new thought patterns on the contemporary info-sphere. Convergence, 5(1), 10-17.

Burgh, G. (2005). From Socrates to Lipman: Making philosophy relevant. In D. Shepherd (Ed.), Creative engagements: Thinking with children (pp. 25-31). Oxford, England: Inter-Disciplinary Press.

Büyüköztürk, Ş., Kılıç-Çakmak, E., Akgün, Ö. E., Karadeniz, Ş., \& Demirel, F. (2012). Bilimsel araştırma yöntemleri (Geliştirilmiş 11. bask1). Ankara: Pegem Akademi.

Creswell, J. W. (2009). Research design: Qualitative, quantitative, and mixed methods approaches. Thousand Oaks, CA: Sage.

de Almeida, Z., \& Benevides, A. (2018). Social skills, coping, resilience and problem solving in psychology university students. Liberabit, 24(2), 265-276. https://doi.org/10.24265/liberabit.2018.v24n2.07

De Bono, E. (1971a). Lateral thinking for management: A handbook. Maidenhead: McGraw - Hill.

De Bono, E. (1971b). The use of lateral thinking. Harmondsworth, Middlesex, England: Pelican.

De Bono, E. (1993). Serious creativity: Using the power of lateral thinking to create new ideas. New York: HarperBusiness.

De Bono, E. (1999). Six thinking hats. Boston: Back Bay Books.

Demirel, T., \& Y1lmaz, T. K. (2019). The effects of mind games in math and grammar courses on the achievements and perceived problem-solving skills of secondary school students. British Journal of Educational Technology, 50(3), 1482-1494.

Docktor, J. L., \& Mestre, J. P. (2014). Synthesis of discipline-based education research in physics. Physical Review Special Topics-Physics Education Research, 10(2), 158. https://doi.org/10.1103/PhysRevSTPER.10.020119.

Dostal, J. (2015). Theory of problem solving. Procedia - Social and Behavioral Sciences, 174, 2798 - 2805.

Duman, B., Yakar, A., Türkoğlu, İ. E., \& Yakar, P. (2013). Türkiye'de öğretmen yetiştirme programları çerçevesinde öğretmen adaylarının kişilik tiplerine göre problem çözme becerilerinin incelenmesi. Hacettepe Üniversitesi Eğitim Fakültesi Dergisi, Özel Sayı(1), 121-143. 
D'Zurilla, T. J., \& Nezu, A. M. (1990). Development and preliminary evaluation of the Social Problem-Solving Inventory. Psychological Assessment: A Journal of Consulting and Clinical Psychology, 2(2), 156-163.

Ecevit, T., \& Kaptan, F. (2019). 21. yüzyıl becerilerinin kazandırılmasına yönelik tasarlanan argümantasyon destekli araştırma-sorgulamaya dayalı öğretim modelinin betimlenmesi. Hacettepe Üniversitesi Eğitim Fakültesi Dergisi. Advance online publication. https://doi.org/10.16986/HUJE.2019056328

Eryılmaz, S., \& Uluyol, Ç. (2015). 21. Yüzyıl becerileri 1şı̆̆ında FATíH projesi değerlendirmesi. Gazi Üniversitesi Gazi Eğitim Fakültesi Dergisi, 35(2), 209-229.

Evin Gencel, İ. (2018). Sınıf Öğretmeni adaylarının yanal düşünme eğilimleri. VIII. Uluslararası Ĕ̈itimde Araştırmalar Kongresi, Bildiri Özetleri Kitabı, s. 48.

Eyvaz, A. (2017). Okul öncesi öğretmen adaylarının problem çözme becerilerinin incelenmesi (Yayınlanmamış Yüksek Lisans Tezi). Doğu Akdeniz Üniversitesi, Gazi Magusa, KKTC.

Frey, K. S., Hirschstein, M. K., \& Guzzo, B. A. (2000). Second step: preventing aggression by promoting social competence. Journal of Emotional and Behavioral Disorders, 30(4), 102-112.

Gravetter, F. J., \& Forzano, L. B. (2012). Research methods for the behavioral sciences (4th ed.). Wadsworth, Cengage Learning: USA.

Guilford, J. P. (1967). Creativity: yesterday, today and tomorrow. The Journal of Creative Behavior, 1(1), 3-14.

Güneri Yöyen, E., Azaklı, A., Üney, R., \& Demirci, O. (2017). Ergenlerin kişilik özelliklerinin problem çözme becerileri üzerine etkisi. Doğu Anadolu Sosyal Bilimlerde Ĕgilimler Dergisi, 1(1), 229-241.

Hamza, T. S., \& Hassan, D. K. (2016). Consequential creativity: Student competency and lateral thinking incorporation in architectural education. International Journal of Technology and Design Education, 26, 587-612.

Hecklau, F., Galaitzke, M., Flachs, S., \& Kohl, H. (2016). Holistic approach for human resource management in Industry 4.0. Procedia CIRP-54, 1-6.

Heppner, P. P., \& Baker, C. E. (1997). Applications of the problem solving inventory. Measurement and Evaluation in Counseling and Development, 29, 229-241.

Heppner, P. P., \& Petersen, C. H. (1982). The development and implications of a personal problem solving inventory. Journal of Counseling Psychology, 29(1), 6675.

Heppner, P. P., Witty, T. E., \& Dixon, W. A. (2004). Problem-solving appraisal and human adjustment: A review of 20 years of research using the problem solving inventory. The Counseling Psychologist, 32(3), 344-428.

Husain, H., Kamal, N., Ibrahim, M. H., Huddin, A. B., \& Alim, A. A. (2017). Endangering problem solving skills and mathematical knowledge via programming. Journal of Engineering Science and Technology, Special Issue on PEKA 2017, 111.

Irwanto, Saputro, A. D., Rohaeti, E., \& Prodjosantoso, A. K. (2018). Promoting critical thinking and problem solving skills of preservice elementary teachers through 
process-oriented guided-inquiry learning (POGIL). International Journal of Instruction, 11(4), 777-794. https://doi.org/10.12973/iji.2018.11449a

Kagermann, H., Wahlster, W., \& J. Helbig, J. (2013). Recommendations for implementing the strategic initiative industrie 4.0: Final report of the industrie 4.0 Working Group. Acatech-National Academy of Science and Engineering, Germany.

Karagöz, B. (2019). An evaluation of pre-service Turkish teachers' lateral thinking dispositions with regard to different variables. European Journal of Educational Studies, 5(9), 156-165.

Karakuş, M. (2001). Eğitim ve yaratıcılı. Ĕgitim ve Bilim, 26(19), 3-7.

Karantzas, G. C., Avery, M. R., Macfarlane, S., Mussap, A., Tooley, G., Hazelwood, Z., \& Fitness, J. (2013). Enhancing critical analysis and problem solving skills in undergraduate psychology: An evaluation of a collaborative learning and problem based learning approach. Australian Journal of Psychology, 65(1), 38-45.

Kolayiş, H., \& Turan, H. (2018). Öğretmen adaylarının algılanan problem çözme becerileri. CBÜ Beden Ĕ̈itimi ve Spor Bilimleri Dergisi, 13(1), 22-32.

Lamb, R., Annetta, L., \& Vallett, D. (2015). The interface of creativity, fluency, lateral thinking, and technology while designing serious educational games in a science classroom. Electronic Journal of Research in Educational Psychology, 13(2), 219242.

Lawrence, A. S. A., \& Xavier, S. A. (2013). Lateral thinking of prospective teachers. Journal of Educational Reflection, 1(1), 28-32.

Lindell, A. K. (2011). Lateral thinkers are not so laterally minded: Hemispheric asymmetry, interaction, and creativity. Laterality: Asymmetries of Body, Brain and Cognition, 16(4), 479-498.

Malik, A., Yuningtias, U. A., Mulhayatiah, D., Chusni, M. M., Sutarno, S., Ismail, A., \& Hermita, N. (2019).Enhancing problem-solving skills of students through problem solving laboratory model related to dynamic fluid. IOP Conf. Series: Journal of Physics: Conf. Series 1157, 1-6.

Matthews, B., \& Ross, L. (2010). Research methods: a practical guide for the social sciences. Pearson Education Limited, Essex: Britain.

Mulyastuti, H., Sutopo, A., \& Taufiq, A. (2018). Identification of high school students' problem-solving skills on rotational dynamics, IOP Conf. Series: Journal of Physics: Conf. Series 1171, 1-14. https://doi.org/10.1088/17426596/1171/1/012028.

Organization for Economic Co-operation and Development [OECD]. (2013). PISA 2012 assessment and analytical framework: Mathematics, reading, science, problem solving and financial literacy. PISAParis: OECD. Retrieved from https://www.oecd.org/pisa/pisaproducts/PISA\%202012\%20framework\%20ebook_final.pdf on July 26, 2019.

Parno, L. Y., \& Ni'mah, B. Q. A. (2018). The influence of PBL-STEM on students' problem solving skills in the topic of optical instruments. IOP Journal of Physics Conference Series 1171, 1-9. https://doi.org/10.1088/1742-6596/1171/1/012013. 
Rossdale, P. D., Martin, C. L., \& Jeffcott, L. B. (2003). Lateral thinking: a different way of benefiting from reading Equine Veterinary Journal and other scientific publications. Equine Veterinary Journal, 35(1), 3-4.

Semerci, Ç. (2016). Yanal Düşünme Eğilimi (YADE) Ölçeğinin geliştirilmesi: Geçerlik ve güvenirlik çalışması. Eğitimde Kuram ve Uygulama Dergisi, 12(1), 358-371.

Semerci, N. (2017). Pedagogical formation students' dispositions toward lateral thinking/pedagojik formasyon öğrencilerinin yanal düşünme eğilimleri. Bartın Üniversitesi Ĕ̈itim Fakültesi Dergisi, 6(1), 336-345.

Senemoğlu, N. (2020). Gelişim, öğrenme ve öğretim: Kuramdan uygulamaya (27. Bask1). Anı Yayınevi: Ankara.

Stahovich, T. F., Van Arsdale, T. S., \& Mayer, R. E. (2019). How handwriting behaviours during problem solving are related to problem-solving success in an engineering course. Contemporary Educational Psychology, 58, 331-337.

Şahin, S., İbili, E., \& Uluyol, Ç. (2017). Öğretmen adaylarında problem çözme ve internet bağımlılığı ilişkisinin incelenmesi. Afyon Kocatepe Üniversitesi Sosyal Bilimler Dergisi, 19(1), 1-21.

Şener, G. (2019). The predictive power of teacher's proactive personality traits on their problem solving skills. Pamukkale Üniversitesi Eğitim Fakültesi Dergisi, 45, 175189.

United Nations Educational, Scientific and Cultural Organization [UNESCO]. (2002). Teacher education guidelines: Using open and distance learning. Retrieved from http://unesdoc.unesco.org/images/0012/001253/125396e.pdf on October 3, 2020.

Ün, E. (2010). Satranç eğitiminin problem çözme yaklaşımları, karar verme ve düşünme stillerine etkisinin incelenmesi (Yüksek Lisans Tezi). Selçuk Üniversitesi Eğitim Bilimleri Enstitüsü, Konya.

Üstündağ, S., \& Beşoluk, Ş. (2012). Fen bilgisi öğretmen adaylarının problem çözme becerilerinin çeşitli değişkenler açısından incelenmesi. X. Ulusal Fen Bilimleri ve Matematik Ĕgitimi Kongresi (27-30 Haziran 2012), Bildiriler Kitab1, Niğde Üniversitesi: Niğde.

Widodo, S. A., Darhim, T., \& Ikhwanudin, T. (2018). Improving mathematical problem solving skills through visual media. Journal of Physics Conference Series-948, 1-8. https://doi.org/10.1088/1742-6596/948/1/012004

Winarti, A., Ichsan, A. N., Listyarini, L., \& Hijriyanti, M. (2019). The effectiveness of collaborative strategy based on multiple intelligences in chemistry learning to improve students' problem-solving skill and multiple intelligences. International Conference on Mathematics and Science Education (ICMScE 2018), Journal of Physics: Conference Series-1157, 1-7. https://doi.org/10.1088/17426596/1157/4/042011

Yıldız, K., \& Yılmaz, B. (2020). Sınıf öğretmenliği adaylarının eleştirel düşünme ve yanal düşünme eğilimleri arasındaki ilişki. Bolu Abant İzzet Baysal Üniversitesi Ĕ̌itim Fakültesi Dergisi, 20(1), 335-353. 